\title{
DEFLECTION DUCTILITY OF SLABS MADE OF HYBRID MESH-AND-FIBRE-REINFORCED CEMENT- BASED COMPOSITE
}

\section{P. B. SAKTHIVEL ${ }^{1}$}

Steel Mesh-Reinforced Cementitious Composites (SMRCC) (traditionally known as ferrocement) have been in existence for few decades, but have some limitations set on element thickness and number of reinforcing mesh layers and the resulting deflection ductility. Therefore, the author has made an attempt to explore whether deflection ductility will improve in mesh-reinforced cementitious composites ( $25 \mathrm{~mm}$ thick) if discontinuous fibres are added to slab elements. For this purpose, thin slab elements of dimensions $700 \mathrm{~mm}$ (length) $\times 200 \mathrm{~mm}$ (width) $\times 25 \mathrm{~mm}$ (thickness) were cast and subjected to four point bending tests. Based on the flexural tests conducted on SMRCC (Control Slab Elements, cast with Steel Mesh Volume of reinforcement, $\mathrm{MV}_{\mathrm{r}}=0.78,0.94$, and 1.23\%) and Hybrid Mesh-and-Fibre-Reinforced Cement Based Composite (HMFRCBC) (Test Slab Elements, combining $\mathrm{MV}_{\mathrm{r}}=0.78,0.94$ and $1.23 \%$ and Polyolefin Fibre Volume fraction, $\mathrm{PO}-\mathrm{FV}_{\mathrm{f}}=0.5-2.5 \%$ of volume of specimens, with $0.5 \%$ interval), load-deflection and the deflection ductility index were analyzed. From the flexural load-deflection curves it has been observed that HMFRCBC slabs demonstrate higher flexural load-carrying capacity and deflection ductility when compared to SMRCC slabs. This study shows that higher the polyolefin fibre volume fraction $\left(\mathrm{PO}-\mathrm{FV}_{\mathrm{f}}\right.$ ) from 0.5 to $2.5 \%$ (with a $0.5 \%$ interval) in HMFRCBC slabs, the higher the flexural deflection ductility. The Deflection Ductility Index (DDI) of HMFRCBC (with 5 layers of mesh and PO-FV $=2.5 \%$ ) is 4.5 times that of SMRCC. This study recommends that HMFRCBC can be used as an innovative construction material due to its higher flexural ductility characteristics.

Keywords: bending, deflection, ductility, hybrid reinforcement, mesh, fibres

\footnotetext{
${ }^{1}$ Ph.D. (TQM), Ph.D. (Civil Eng.), Professor \& Head, Department of Civil Engineering, Misrimal Navajee Munoth Jain Engineering College (Affiliated to Anna University, Chennai), Chennai-600 067, Tamil Nadu, India, e-mail: pbs_ms@yahoo.com
} 


\section{INTRODUCTION}

Steel Mesh-reinforced Cementitious Composite (SMRCC, traditionally known as ferrocement) is an innovative material made up of hydraulic cement mortar and tightly-spaced layers of continuous small-diameter steel wire mesh to create a stiff structural form and it is used as a component of precast roofing slab elements due to its excellent modulus of rupture [1-4]. Even though several ferrocement structures (like precast and cast-in-situ primary and secondary roofs and beam elements, wall panels, earth retaining walls, precast staircase, benches, pyramids, domes, thin pergolas and sunscreens, sea facing walls, overhead water tanks, underground sumps, swimming pools and boats) have been constructed throughout the world over the last several decades, there are some limitations. One such

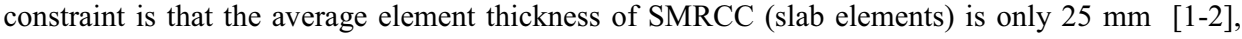
restricting the thickness of mesh to 4-5 layers; further increase in mesh layers leads to congestion in the mesh, problems in minimum coverage to reinforce the mesh, spalling of the cementitious matrix, and delamination of the extreme tensile layer resulting in premature failure of the element [1-2], [57]. Furthermore, SMRCC thickness also adversely affects the flexural performance and ductility of slab elements under a particular loading condition [8]. Deflection ductility demonstrates the ability of the flexural member (slab elements) to deform at or near the ultimate failure load without a significant loss in strength.

In order to improve the deflection ductility of ferrocement elements, previous studies [5, 9-13] have recommended that discontinuous fibres of a volume fraction of 0.5 to $2.5 \%$ (with a $0.5 \%$ interval) be added to the cementitious matrix of SMRCC. A new hybrid cementitious composite using mesh and fibre reinforcement in combined form have been suggested for improving strength and ductility performance by several authors [1],[6]. For example, Wang et al. (2004) [6] combined mesh (Expanded Steel Mesh and Kevlar FRP mesh) and discontinuous fibres (Polyethylene Spectra fibre and Poly-vinyl Alcohol (PVA) fibre with a volume fraction of $1.5 \%$ and $2 \%$, respectively) in cementitious composites and noted an increase in the modulus of rupture and ductility performance. Synthetic fibres made up of nylon, polypropylene, polyethylene, and PVA are used in cement-based composites as reinforcement as they are corrosion-resistant to alkalis, acids, and salts [14-15]. Since polymeric fibres are non-degradable when used with cement [16], they are recommended as reinforcement in cement-based composites.

The deflection ductility of a brittle matrix (such as cement mortar) is improved with the addition of discontinuous fibres [17] and its flexural ductile behavior gives early warning signs aiding in the 
prevention of sudden, unexpected, and catastrophic failures of the structural elements in question [18]. Deflection ductility of a structural element (slab, beam) is determined by experiments employing simple flexural tests [17-18] based on mid-span deflection [19-21]. Previous studies [1], [5], [10-12], [22-23] have shown that deflection ductility behavior is characterized by the ability to sustain higher levels of loading after the first cracking while undergoing a large deformation [17]. The deflection ductility at the first crack and the ultimate load bearable in cement-based composites depends upon element thickness, type of reinforcement (mesh and/ or fibres), and the volume fraction (percentage) of mesh and fibres [1], [10-12]. Combining mesh and fibres in thin cementitious composites will result in improved flexural ductility performance [1], [10-12], [18], [24-25]. Since a detailed study is needed to understand the flexural load-deflection behavior of thin slab elements reinforced with mesh and fibres and deflection ductility behavior [10-12], [18], the present study has made an attempt to combine steel mesh and polyolefin fibres as reinforcement in hybrid form and study its flexural deflection ductility.

\section{EXPERIMENTAL INVESTIGATION}

\subsection{RESEARCH OBJECTIVES}

Steel Mesh-Reinforced Cementitious Composite (SMRCC, slab elements) has limitations in terms of element thickness and ductility. Therefore, the study presented in this paper has chosen to add polyolefin fibre to the cementitious matrix (reinforced with steel weld mesh) and conduct flexural studies on Hybrid Mesh-and-Fibre-Reinforced Cement Based Composites (HMFRBC, Test Slab Elements) and study the first crack load and ultimate load and its corresponding mid-span deflection and evaluate its deflection ductility performance in comparison with SMRCC (Control Slab Elements). Slab elements $700 \mathrm{~mm}$ (length) $\times 200 \mathrm{~mm}$ (width) $\times 25 \mathrm{~mm}$ (thickness) have been used in this study. Several hybrid reinforcing mix combinations of Steel Mesh (SM) of 3, 4, and 5 layers and Polyolefin (PO) Fibres (with a Fibre Volume fraction of $\mathrm{FV}_{\mathrm{f}}=0$ to $2.5 \%$, with $0.5 \%$ interval) are used in the slab, as shown in Table 1 and explained in Section 2.1.1. The load-deflection behaviors of slabs are studied under flexural loads and the Deflection Ductility Index (DDI) of HMFRCBC has been calculated and compared with SMRCC (cast with SM of 3, 4, and 5 layers) and presented in the forthcoming sections. 


\subsubsection{Identification of Test And Control Slab Elements}

Slabs to be cast and tested are shown in Table 1. For various Slab Types, CS3, CS4, and CS5 under SMRCC, the Mesh Volume of reinforcement $\left(\mathrm{MV}_{\mathrm{r}}\right)$ of steel mesh (SM) reinforcement used are $0.74,0.98$, and $1.23 \%$, respectively. For HMFRCBC, under Slab Types 3A to 3E, hybrid mesh-andfibre reinforcement combining three layers of $\mathrm{SM}$ (Constant $\left.\mathrm{MV}_{\mathrm{r}}=0.74 \%\right)$ and of varying Polyolefin Fibre Volume fractions (PO-FV $\mathrm{f}_{\mathrm{f}}$ of $0.5-2.5 \%$ (respectively) has been used. For HMFRCBC of Types 4A to $4 \mathrm{E}$, four layers of $\mathrm{SM}$ (Constant $\mathrm{MV}_{\mathrm{r}}=0.98 \%$ ) and varying $\mathrm{PO}-\mathrm{V}_{\mathrm{f}}$ of $0.5-2.5 \%$ (respectively) and for Types $5 \mathrm{~A}$ to $5 \mathrm{E}$, five layers of $\mathrm{SM}$ (constant $\mathrm{MV}_{\mathrm{r}}=1.23 \%$ ) and varying $\mathrm{PO}-\mathrm{V}_{\mathrm{f}}$ of $0.5-2.5 \%$ (respectively) are provided. Since the thickness of each slab is only $25 \mathrm{~mm}$ and the reinforcing mesh cover (at the top and bottom) is $3 \mathrm{~mm}$, the maximum no. of mesh layers that could be accommodated in the slab elements in SMRCC and HMFRCBC is 5 layers.

Table 1 Specimen Identification and Reinforcement of SMRCC and HMFRCBC (Slabs)

\begin{tabular}{|c|c|c|c|}
\hline Slab Reference & ML (of SM) & $\mathbf{M V}_{\mathbf{r}}$ & PO-FV $_{\mathbf{f}}$ \\
\hline No. & Nos. & $\mathbf{\%}$ & \% \\
\hline CS3 & 3 & 0.74 & 0.0 \\
\hline 3A & 3 & 0.74 & 0.5 \\
\hline 3B & 3 & 0.74 & 1.0 \\
\hline 3C & 3 & 0.74 & 1.5 \\
\hline 3D & 3 & 0.74 & 2.0 \\
\hline 3E & 3 & 0.74 & 2.5 \\
\hline CS4 & 4 & 0.98 & 0.0 \\
\hline 4A & 4 & 0.98 & 0.5 \\
\hline 4B & 4 & 0.98 & 1.0 \\
\hline 4C & 4 & 0.98 & 1.5 \\
\hline 4D & 4 & 0.98 & 2.0 \\
\hline 4E & 4 & 0.98 & 2.5 \\
\hline CS5 & 5 & 1.23 & 0.0 \\
\hline 5A & 5 & 1.23 & 0.5 \\
\hline 5B & 5 & 1.23 & 1.0 \\
\hline 5C & 5 & 1.23 & 1.5 \\
\hline 5D & 5 & 1.23 & 2.0 \\
\hline 5E & 5 & 1.23 & 2.5 \\
\hline
\end{tabular}

Note: SMRCC (Steel Mesh-Reinforced Cementitious Composites) - Slab Type CS3, CS4, CS5; HMFRCBC-Hybrid Mesh-and-Fibre-Reinforced Cement Based Composites - Slab Type 3A to 3E, 4A to 4E and 5A to 5E; SM-Steel Mesh; ML-No. of Mesh Layers, $\mathrm{MV}_{\mathrm{r}}=$ Mesh Volume of Reinforcement; PO$\mathrm{FV}_{\mathrm{f}}(\%)=$ Polyolefin Fibre Volume Fraction percentage 


\subsection{Casting of Specimens}

\subsubsection{Materials AND Mix Proportions}

Properties of steel weld mesh are shown in Table 2. Steel mesh with a diameter, $d_{w}$ of $0.7 \mathrm{~mm}$, square grid opening size, $\mathrm{D}$ of $12.5 \mathrm{~mm}$, satisfies the requirements of $0.5 \leq \mathrm{d}_{\mathrm{w}} \leq 1.5 \mathrm{~mm}$ and $6 \leq \mathrm{D} \leq$ $25 \mathrm{~mm}$ (respectively) [26]. The steel mesh used has tensile and yield strength of 512.36 and 406.51 $\mathrm{N} / \mathrm{mm}^{2}$ (respectively), elongation of $7.12 \%$, weld shear of $250 \mathrm{~N} / \mathrm{mm}^{2}$, and a density of $7.82 \mathrm{~g} / \mathrm{cm}^{3}$. Polyolefin (PO) (Bar-chip $54 \mathrm{~mm}$ ) fibres with an aspect ratio of 101.8 of a continuously embossed type manufactured by Elasto Plastic Concrete (EPC, Australia) have been employed in the present study and their properties are shown in Table 3 . The PO fibres have a specific gravity of 0.92 , young's modulus of $10 \mathrm{GPa}$, a melting point of $150^{\circ} \mathrm{C}$ to $170^{\circ} \mathrm{C}$, and an ignition point greater than $450^{\circ} \mathrm{C}$.

Naaman [1], ACI Report [2], Al-Rifaie and Joma'ah (2010) [26], and Sakthivel et al. (2015, 2016) [10-12] have indicated that a sand-cement (s/c) ratio between 1 and 3 and a water-cement (w/c) ratio of 0.35 to 5.0 are most suitable for a fully compacted matrix with low permeability and low porosity. Accordingly, here the author has tried several trial mixes and finalized the s/c ratio of 2:1 and the w/c ratio of 0.43. Reference Control Specimens (RCS) and Reference Test Specimens (RTS) are given in Section 2.2.2. Also, for casting SMRCC (Control Slab Elements) and HMFRCBC (Test Slab Elements), the same cement mortar used in RCS and RTS respectively with the above-mentioned $\mathrm{s} / \mathrm{c}$ and $\mathrm{w} / \mathrm{c}$ ratios has been used. In this study, plain cement mortar is used in casting SMRCC slabs, and polyolefin fibrous mortar is used for HMFRCBC slabs.

The maximum $\mathrm{PO}-\mathrm{V}_{\mathrm{f}}(\%)$ adopted in this study is $2.5 \%$, because the author experienced difficulties while mixing $\mathrm{PO}-\mathrm{V}_{\mathrm{f}}(\%)$ of more than $2.5 \%$ in plain cement mortar, and, to further avoid workability related issues, $\mathrm{PO}-\mathrm{V}_{\mathrm{f}}(\%)$ has been restricted to $2.5 \%$ for experimental purposes $[10-13$, 24].

Ordinary Portland Cement (OPC-53 Grade) was used for casting specimens which conform to IS 12269-1987 [27] standards. The fine aggregate used is natural river sand, and this material occupies the largest volume in the cementitious matrix as no coarse aggregate is used in the mix. River sand passing 100 percent through a $2.36 \mathrm{~mm}$ sieve, retaining at most 15 percent in the $0.15 \mathrm{~mm}$ mesh sieve [2-4], and conforming to Zone II of IS 383: 1987 [28] has been used. 
Table 2 Properties of Steel Weld Mesh

\begin{tabular}{|c|c|}
\hline Properties & Results \\
\hline Tensile Strength $\left(\mathrm{N} / \mathrm{mm}^{2}\right)$ & 512.36 \\
\hline Yield Strength $\left(\mathrm{N} / \mathrm{mm}^{2}\right)$ & 406.51 \\
\hline Elongation $(\%)$ & 7.12 \\
\hline Weld Shear $\left(\mathrm{N} / \mathrm{mm}^{2}\right)$ & 250 \\
\hline Density $\left(\mathrm{g} / \mathrm{cm}^{3}\right)$ & 7.82 \\
\hline Mesh Grid Opening Size $(\mathrm{D})(\mathrm{mm})$ & 12.5 \\
\hline Diameter $\left(\mathrm{d}_{\mathrm{w}}\right)(\mathrm{mm})$ & 0.70 \\
\hline Coating thickness $($ Zinc) $($ in microns) & $4-6$ \\
\hline
\end{tabular}

Table 3 Properties of Polyolefin Fibres

\begin{tabular}{|c|c|}
\hline Properties & Results \\
\hline Brand Name & Barchip-54 \\
\hline Base Material & Modified Olefin \\
\hline Length of Fibre & $54 \mathrm{~mm}$ \\
\hline Aspect Ratio & 101.89 \\
\hline Tensile Strength & $640 \mathrm{MPa}$ \\
\hline Surface Texture & Continuously Embossed \\
\hline Specific Gravity & $0.90-0.92$ \\
\hline Young's Modulus & $10 \mathrm{GPa}$ \\
\hline Melting Point & $150^{\circ} \mathrm{C}$ to $170^{\circ} \mathrm{C}$ \\
\hline Ignition Point & Greater than $450^{\circ} \mathrm{C}$ \\
\hline
\end{tabular}

\subsubsection{ReFERENCE CONTROL AND TEST SPECIMENS}

The compressive strength and split tensile strength test results of hardened plain cement mortar and polyolefin fibrous mortar used in SMRCC and HMFRCBC are determined by testing Reference Control Specimens (RCS) and Reference Test Specimens (RTS), respectively. Plain cement mortar and polyolefin fibrous mortar for RCS and RTS, respectively, are cast in cylinders measuring 100 $\mathrm{mm} \times 200 \mathrm{~mm}$ (height) with the prismatic flexural strength of beams $40 \mathrm{~mm} \times 40 \mathrm{~mm} \times 160 \mathrm{~mm}$ in dimensions, and then tested.

For casting RCS, a sand cement $(\mathrm{s} / \mathrm{c})$ ratio of 2:1 is initially mixed in a dry state, the required amount of water is then added to the plain cement mortar as per the w/c ratio of 0.43 and thoroughly mixed, and finally cast in the above-mentioned cylindrical moulds. For RTS, the dry cement mortar is first prepared with $\mathrm{s} / \mathrm{c}$ of $2: 1$, and then polyolefin fibre is evenly spread into the dry mortar and well mixed. To the dry fibrous mortar, water (w/c of 0.43 ) is gradually added and thoroughly mixed, and now the wet fibrous mortar is used for casting the RTS. For casting RTS-A, B, C, D, and E type mixes shown in Table 4, polyolefin fibre volume fractions (PO-FV $\mathrm{f}_{\mathrm{f}} \%$ ) of $0.5,1.0,1.5,2.0$, and 2.5\%, respectively, is added to the plain cement mortar in a dry state. All the specimens cast were demoulded after 24 hours and stored in water bath until testing (28 days). 
The strength test results of RCS and RTS tested at 28 days are shown in Table 4 . In Table 4 it is seen that for RCS and RTS-A, B, C, D, E type mixes, the compressive strength is $25.48,30.57,33.12$, $35.67,38.22$, and $48.41 \mathrm{~N} / \mathrm{mm}^{2}$, respectively; split-tensile strength is $4.56,4.78,5.60,5.83,6.37$, and $7.43 \mathrm{~N} / \mathrm{mm}^{2}$, respectively; and flexural strength is $5.36,6.32,6.45,7.58,8.34$, and $8.97 \mathrm{~N} / \mathrm{mm}^{2}$, respectively, all at 28 days.

To study the consistency of mortar flow [1-6], [10-12], slump cone and flow tests were conducted on plain cement mortar and polyolefin fibrous cement mortar. In Table 4, it can be seen that there is a decline in slump value from 70 to $20 \mathrm{~mm}$ for RTS A to E, and from 70 to $20 \mathrm{~mm}$ when the polyolefin fibre amount is increased in cement mortar from 0.5 to $2.5 \%$ (with a $0.5 \%$ interval), respectively (comparing to $85 \mathrm{~mm}$ for RCS). Also, when PO- $\mathrm{V}_{\mathrm{f}}(\%)$ is increased from 0.5 to $2.5 \%$ (with a $0.5 \%$ interval), the flow efficiency of polyolefin fibrous cement mortar falls from 75 to $25 \%$ for RTS A to E, respectively, when compared to $92 \%$ for RCS. This demonstrates that when polyolefin fibre is added to plain cement mortar, the flow and consistency is reduced. It has been established that the higher the polyolefin fibre volume fraction in cement mortar, the lower the workability of the mix.

Table 4 Strength of Reference Control and Test Specimens

\begin{tabular}{|c|c|c|c|c|c|c|c|c|c|}
\hline \multirow[t]{2}{*}{ Type } & \multirow[t]{2}{*}{$\begin{array}{l}\text { Cement- } \\
\text { Sand } \\
\text { Ratio }\end{array}$} & \multirow[t]{2}{*}{$\begin{array}{l}\text { Water- } \\
\text { Cement } \\
\text { Ratio }\end{array}$} & $\begin{array}{c}\text { Fibre } \\
\text { Volume } \\
\text { Fraction } \\
\left(\mathrm{FV}_{\mathrm{f}}\right) \\
\end{array}$ & \multirow[t]{2}{*}{$\begin{array}{l}\text { Fibre } \\
\text { Aspect } \\
\text { Ratio } \\
\text { (FAR) }\end{array}$} & Slump & Flow & $\begin{array}{c}\text { Cylinder } \\
\text { Compressive } \\
\text { Strength } \\
\text { (at } 28 \text { days) }\end{array}$ & $\begin{array}{l}\text { Split-tensile } \\
\text { Strength } \\
\text { (at } 28 \text { days) }\end{array}$ & $\begin{array}{l}\text { Prismatic } \\
\text { Flexural } \\
\text { Strength } \\
\text { (at 28 days) }\end{array}$ \\
\hline & & & $(\%)$ & & $(\mathrm{mm})$ & $\%$ & $\left(\mathrm{~N} / \mathrm{mm}^{2}\right)$ & $\left(\mathrm{N} / \mathrm{mm}^{2}\right)$ & $\left(\mathrm{N} / \mathrm{mm}^{2}\right)$ \\
\hline RCS & 0.5 & 0.43 & 0.0 & 101.89 & 85 & 92 & 25.48 & 4.56 & 5.36 \\
\hline RTS-A & 0.5 & 0.43 & 0.5 & 101.89 & 70 & 75 & 30.57 & 4.78 & 6.32 \\
\hline RTS-B & 0.5 & 0.43 & 1.0 & 101.89 & 40 & 64 & 33.12 & 5.60 & 6.45 \\
\hline RTS-C & 0.5 & 0.43 & 1.5 & 101.89 & 35 & 41 & 35.67 & 5.83 & 7.58 \\
\hline RTS-D & 0.5 & 0.43 & 2.0 & 101.89 & 25 & 36 & 38.22 & 6.37 & 8.34 \\
\hline RTS-E & 0.5 & 0.43 & 2.5 & 101.89 & 20 & 25 & 48.41 & 7.43 & 8.97 \\
\hline
\end{tabular}

Note: RCS-Reference Control Specimens; RTS-A,B,C,D,E-Reference Test Specimens with $\mathrm{FV}_{\mathrm{f}}(\%)=0.5,1.0,1.5,2.0$ and $2.5 \%$ (respectively)

\subsubsection{Casting Procedure of Control and Test Slab Elements}

For the purpose of conducting flexural tests on $700 \mathrm{~mm}$ (length) $\times 200 \mathrm{~mm}$ (width) $\times 25 \mathrm{~mm}$ (thickness) samples described under SMRCC (Control Slab Elements) as Slab Types, CS3, CS4, and CS5, and HMFRCBC (Test Slab Elements) as Slab Types 3A to 3E, 4A to 4E, and 5A to 5E as 
detailed in Table 1, with various combinations of mesh (in $\mathrm{MV}_{\mathrm{r}} \%$ ) and Polyolefin fibres (in PO$\mathrm{FV}_{\mathrm{f}} \%$ ).

The SMRCC and HMFRCBC slabs are cast in aluminum moulds as shown in Fig. 1. The 28-day strength (compressive, split tensile, and flexural strength) results of hardened plain cement mortar (concerning SMRCC slabs) and polyolefin fibrous cement mortar (concerning HMFRCBC slabs) are already represented under RCS and RTS, respectively, in Table 4.

For casting SMRCC slabs, plain cement mortar is laid as a $3 \mathrm{~mm}$ base cover (first layer) at the bottom of the moulds, and the mortar is evenly spread with a mason's trowel, the top surface is then properly finished. Next, the first layer of steel mesh is laid over this evenly-finished base mortar cover. Over this first layer of mesh plain cement mortar is laid, and after spreading the mortar neatly and finishing the top surface the second mesh layer is placed over the mortar. The process is repeated until the desired number of mesh layers (3, 4, 5 nos.) is laid. A reinforcing cover of $3 \mathrm{~mm}$ is ensured at the top and bottom mesh layers as well as in-between the reinforcing mesh layers (using $3 \mathrm{~mm}$ glass spacers which are removed after pouring the mortar). At each stage, it has been ensured that the mortar is manually compacted by hand, casting pressure using a mason's trowel, and finished properly before adding the next layer of mesh reinforcement.

Similarly, the procedure used for SMRCC is adopted for casting HMFRCBC slabs, except that the plain cement mortar is replaced with polyolefin fibrous cement mortar.

After 24 hours of hardening, slab elements were demoulded and moist-cured for 28 days. The SMRCC and HMFRCBC slab elements were cleaned of dust and dirt, if any was present, and whitewashed and dried, and unique identification marks were given using indelible ink. The testing of the slabs is described in Section 2.3.

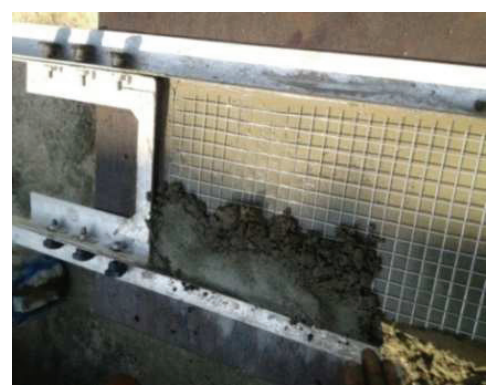




\subsection{Flexural LoAd Deflection Tests}

Flexural tests have been conducted in line with the Research Objectives identified in Section 2.1, and the load-deflection and ductility of SMRCC and HMFRCBC slabs has been evaluated [3], [5], [10-12] [19-21]. The flexure loading test was conducted on the simply supported slab specimens with a span length of $600 \mathrm{~mm}$ and loaded at one-third and two-third points (200 and $400 \mathrm{~mm}$ from slab support ends) through a spreader beam (as shown in Fig.2), thereby providing a pure bending in the central moment region of the slab. The flexural load and the mid-point deflection of the slab elements were determined using a load cell and a linear variable differential transducer (LVDT), respectively [29-30]. The flexural loading setup (shown in Fig.2) with a four point bending fixture arrangement eliminating extraneous deformations related to seating, twisting, or support settlements and specimen rotations [10-12], [19-22], [31] was fabricated for the test in line with the JCSE standards [32] and ASTM code provisions [33].

The flexural loading apparatus (Fig.2) has been inverted to better observe the visible cracks formed on the SMRCC and HMFRCBC slab elements - on their tension side - during the tests. The load was manually applied in small increments using a hydraulic jack, and for every load increment (measured by a load cell) the corresponding deflection was recorded by a computerized dataacquisition system. For each load increment, the first-crack noticeable to the naked eye as well as cracks which appeared on the top face of the slab in the bending moment region were carefully observed. The load-deflection behavior of the SMRCC and HMFRCBC slabs has been brought out in Section 3.

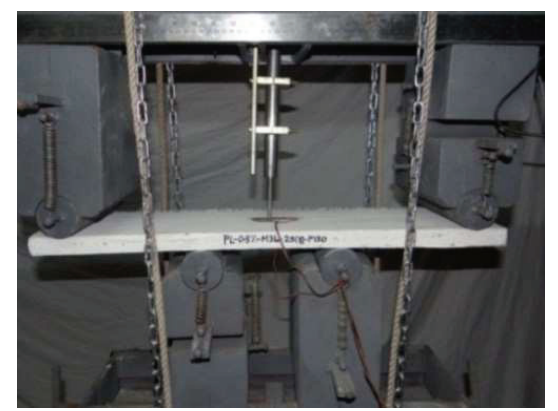

Fig. 2. Flexural Test Set-up (with test specimen) 


\section{RESULTS \& DISCUSSION}

\subsection{FLEXURAL LOAD AND DEFLECTION}

The experimental test results of SMRCC and HMFRCBC are presented in Table 5. The flexural load deflection curves of Slab Types CS3 and 3A to 3E, CS4 and 4A to 4E, and CS5 and 5A to 5E are shown in Figs. 3, 4, and 5, respectively. Even though many pilot studies on slab elements were conducted by the author (results are not presented in this study), only the main study results conducted with a higher level of accuracy are referred to in this study.

From the load-deflection curves presented in Figs. 3, 4, and 5, it is noticeable that the slabs demonstrate a linear elastic behavior of the load deflection points up to the first crack, showing an increase in initial stiffness, and, after the initiation of the first crack, the curve then becomes nonlinear. From Table 5 and Figs. 3, 4, and 5, it can be seen that the flexural load values at first crack ( $\mathrm{P}_{\text {cr }}$ ) for Slab Types CS3, CS4, and CS5 are $1.45 \mathrm{kN}, 1.65 \mathrm{kN}$, and $1.75 \mathrm{kN}$ with mid-span deflection at first crack $\left(\delta_{\text {cr }}\right)$ of $2.87 \mathrm{~mm}, 2.65, \mathrm{~mm}$ and $2.56 \mathrm{~mm}$, respectively. Similarly, the ultimate load $\left(\mathrm{P}_{\mathrm{u}}\right)$ of Types CS3, CS4, and CS5 showing specimen failure are $1.60 \mathrm{kN}, 2.05 \mathrm{kN}$, and $2.65 \mathrm{kN}$, respectively, with an ultimate deflection $\left(\delta_{\mathrm{cr}}\right)$ of $3.84 \mathrm{~mm}, 5.74 \mathrm{~mm}$, and $6.10 \mathrm{~mm}$. As the number of mesh layers in SMRCC increases from 3 to 5 numbers, an increase in the flexural load and a corresponding decrease in mid-span deflection at first crack is noted, demonstrating improvement in stiffness, and, beyond first crack, the deflection ductility improves at ultimate loads similar to the study results of Arif et al. (1999) [34]; Masood et al. (2003) [35]; Gweli et al. (2007) [36]; and Cheah and Ramli (2012) [37].

In the study of Hossain et al. (2005) [38], the bearing capacity at first crack and ultimate loads of the cement composite elements in flexure increase with the increase in percent effective reinforcement (when geogrid and chicken mesh was used), irrespective of slab thickness. Also, the research done by Phalke and Gaidhankar (2014) [39] on flexural behaviours of ferrocement slab panels $550 \mathrm{~mm} \times 200 \mathrm{~mm}$ (of thickness $25 \mathrm{~mm}$ ) in size, with a s/c ratio of 1:1.75 and a w/c ratio of 0.38 , and using 3 and 4 layers of welded square mesh incorporating steel fibres of $\mathrm{V}_{\mathrm{f}}=0.5 \%$, showed first crack deflection of $5.47 \mathrm{~mm}$ and $5.95 \mathrm{~mm}$, respectively, and ultimate deflection of 12.10, and $7.3 \mathrm{~mm}$, respectively, and the control specimens (with only 3 and 4 mesh layers) showed first crack deflection of $5.89 \mathrm{~mm}$ and $4.58 \mathrm{~mm}$, respectively, and ultimate deflection of $6.89 \mathrm{~mm}$ and $11.32 \mathrm{~mm}$, respectively. Thus, first crack load and ultimate load increases with an increase in the reinforcement 
volume fraction; it is observed that the reinforcement volume fraction has a pronounced effect on ultimate load values.

Similarly, for HMFRCBC, it was observed that when the polyolefin fibre volume fraction was increased (along with mesh), there was an increase in the flexural load, with a decrease in mid-span deflection at first crack, demonstrating higher stiffness. As the flexural load was constantly increased, the ductility further improved, and multiple cracks were noticed in the moment region in the HMFRCBC slabs, demonstrating a not at all sudden and catastrophic but instead a slow and steady failure pattern, demonstrating the importance of ductility and validating HMFRCBC as an innovative construction material. The higher the hybrid mesh-and-fibre reinforcement (volume fraction), higher the deflection ductility.

Table 5 shows that the HMFRCBC Slab Types $3 \mathrm{~A}$ to $3 \mathrm{E}, 4 \mathrm{~A}$ to $4 \mathrm{E}$, and $5 \mathrm{~A}$ to $5 \mathrm{E}$ see an increase in first crack flexural load $\left(\mathrm{P}_{\mathrm{cr}}\right)$ of 1.50 to $2.05 \mathrm{kN}, 1.85$ to $2.20 \mathrm{kN}$ and 2.20 to $2.30 \mathrm{kN}$ respectively, and the corresponding reduction in first crack deflection $\left(\delta_{\mathrm{cr}}\right)$ from 2.15 to $1.54 \mathrm{~mm}, 1.93$ to $1.48 \mathrm{~mm}$, and 1.62 to $1.19 \mathrm{~mm}$, respectively. A similar trend of increase in flexural load (or equivalent flexural strength) is reported in the research of Ahamed and Mihashi (2011) [40].

From Table 5, it can be seen that for Slab Types $3 \mathrm{~A}$ to $3 \mathrm{E}, 4 \mathrm{~A}$ to $4 \mathrm{E}$, and $5 \mathrm{~A}$ to $5 \mathrm{D}, \mathrm{P}_{\mathrm{u}}$ shows an increase of 1.85 to $2.7 \mathrm{kN}, 2.60$ to $3.45 \mathrm{kN}$, and 2.80 to $3.70 \mathrm{kN}$, respectively, and for Type 5E, it is reduced to $3.30 \mathrm{kN}$. Accordingly, $\delta_{\mathrm{u}}$ has increased for Types $3 \mathrm{~A}$ to $3 \mathrm{E}$ from 4.85 to $12.96 \mathrm{~mm}$, Types $4 \mathrm{~A}$ to $4 \mathrm{E}$ from 7.35 to $12.16 \mathrm{~mm}$, and Types $5 \mathrm{~A}$ to $5 \mathrm{D}$ from 7.73 to $13.85 \mathrm{~mm}$, respectively, and for Type 5E, $\delta_{\mathrm{u}}$ shows $12.74 \mathrm{~mm}$. Overall, it is observed that the higher the volume fraction of mesh and/or fibres, the higher the flexural load (or equivalent flexural strength) of HMFRCBC slab elements [41]. In a similar study, Abushawashi and Vimonsatit (2014) [42] used hybrid PVA fibre and steel wire mesh in fibrous ferrocement slab panels measuring $620 \times 200 \times 25 \mathrm{~mm}$ (thickness) with $\mathrm{MV}_{\mathrm{r}}=0.80 \%$ (3 mesh layers) and PVA $\mathrm{V}_{\mathrm{f}}=1.5 \%$, which showed first crack and ultimate deflection of $0.57 \mathrm{~mm}$ and $10.38 \mathrm{~mm}$, respectively.

Judging by the load deflection curves in Figs. 3, 4, and 5, HMFRCBC has withstood higher levels of loading after first cracking and there seems to be an improvement in deflection ductility when compared to SMRCC [18]. The deflection hardening behavior is confirmed in HMFRCBC, since multiple cracks formed between the first crack and the ultimate load; also, the ultimate load is higher than the first crack load [23], and the deflection at ultimate load is greater than the first crack deflection. The deflection hardening noted also demonstrates that the material's post-crack flexural strength is higher than its first cracking strength. From the load deflection curves of HMFRCBC (Types $3 \mathrm{~A}$ to $3 \mathrm{E}, 4 \mathrm{~A}$ to $4 \mathrm{E}$, and $5 \mathrm{~A}$ to $5 \mathrm{E}$ in Figs.3,4 and 5 respectively), it can be seen that at the 
initial stages there is linear elastic behavior present, and once linearity has ceased (beyond first crack), a strain-hardening trend (in the form of multiple cracks in the moment area) is witnessed, and the dissipation of energy has resulted in a more ductile response. This study, however, focuses specifically on flexural deflection ductility and not on multiple cracking. The load-deflection values also show that HMFRCBC slabs incorporating mesh and fibres are able to undergo large deflection at ultimate loads due to the ductility values improved by the polyolefin fibres in the matrix; flexural strength increases with an increase in the polyolefin fibre volume fraction. The higher the fibre volume fraction, the greater the Deflection Ductility of HMFRCBC slabs.

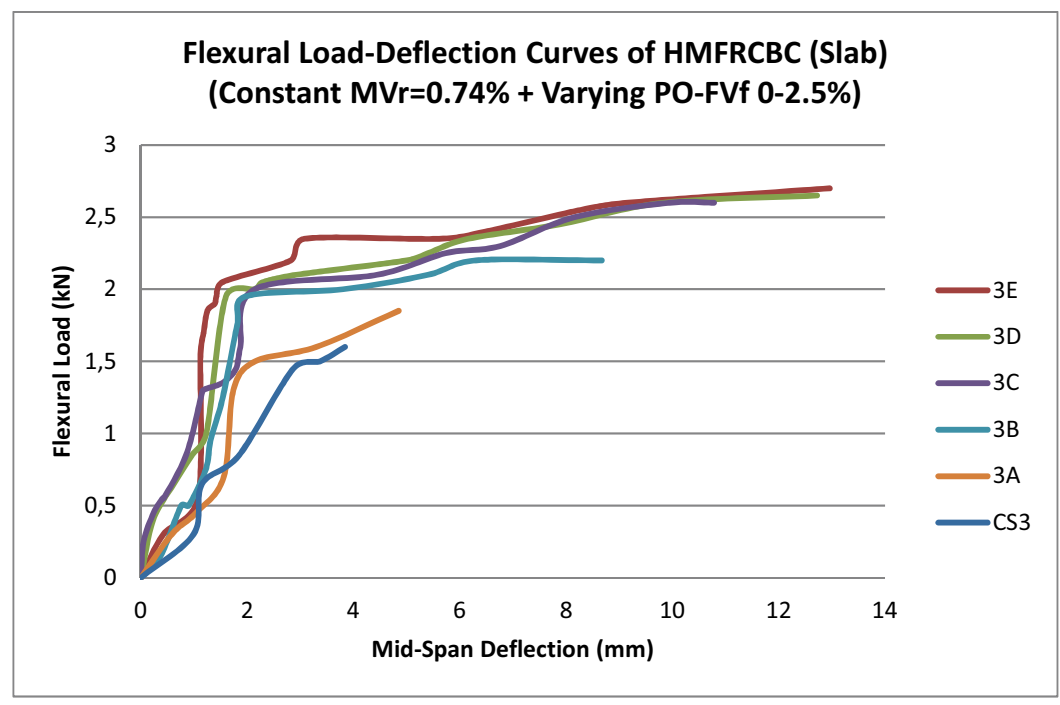

Fig. 3. Flexural Load-Deflection Curves

(for Specimens CS3 \& $3 \mathrm{~A}$ to $3 \mathrm{E}$ ) 


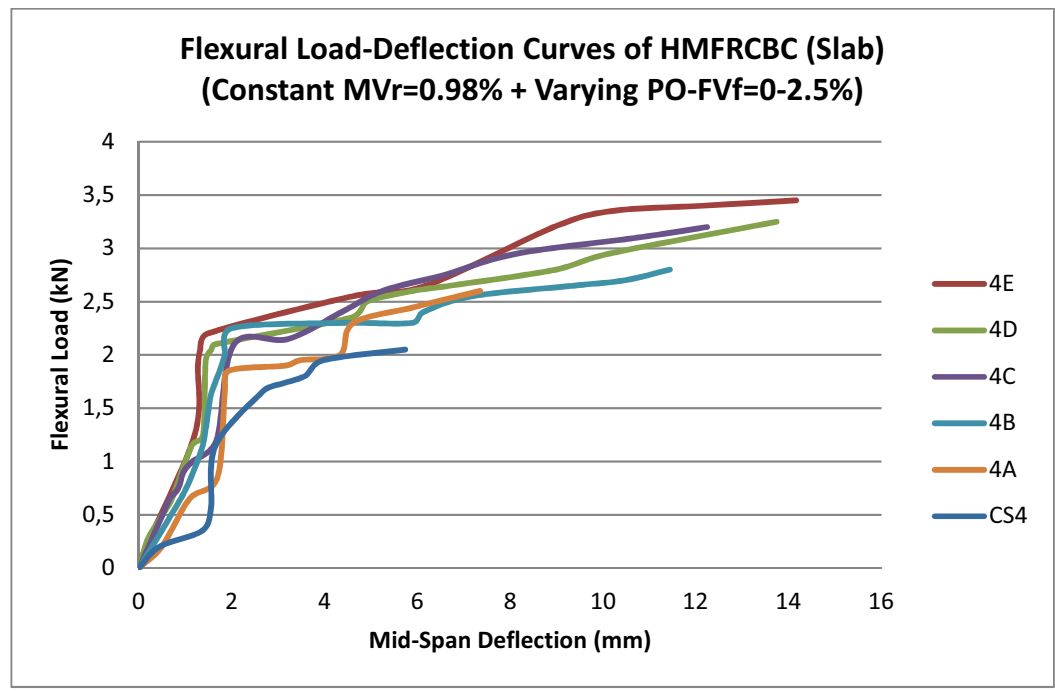

Fig. 4. Flexural Load-Deflection Curves

(for Specimens CS4 \& 4A to 4E)

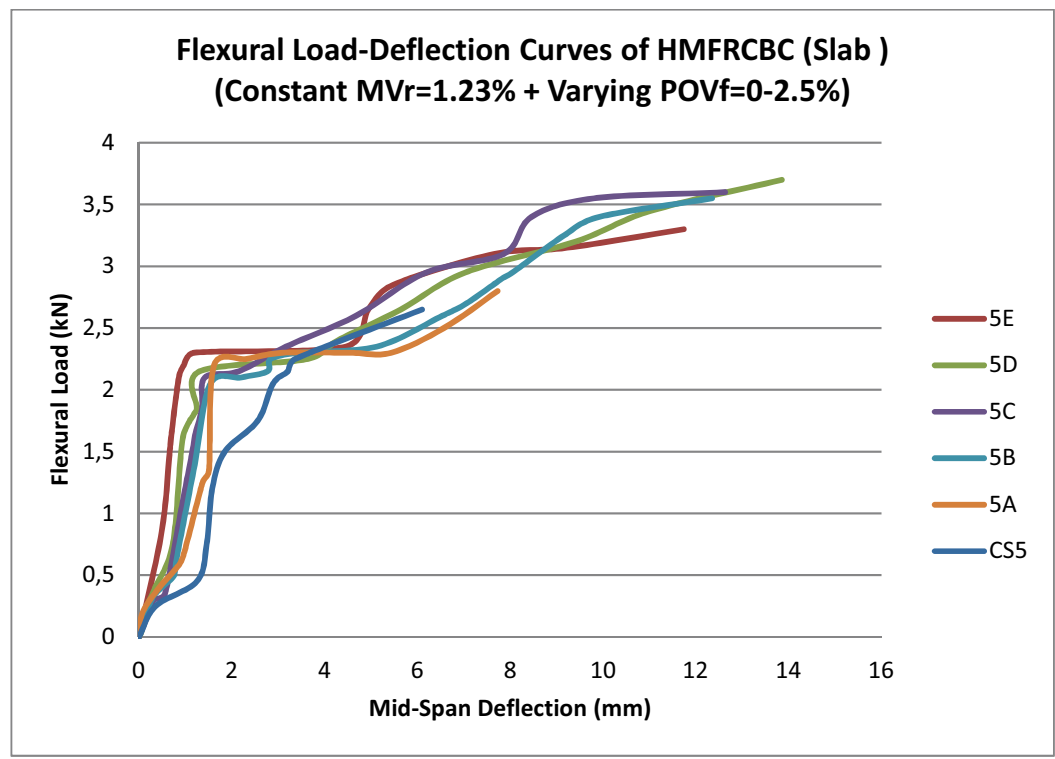

Fig. 5. Flexural Load-Deflection Curves

(for Specimens CS5 \& 5A to 5E) 


\subsection{DEFLECTION DUCTILITY}

Deflection ductility, the ratio between mid-span deflection at ultimate load and first crack load $\left(\delta_{\mathrm{u}} / \delta_{\mathrm{cr}}\right)$, is calculated using the formulae of Masood et al. (2003) [35] and Shaikh (2013) [43] as given in Eq. (3.1) and presented in Table 5:

$$
\text { Ductility Index }=\delta_{\mathrm{u}} / \delta_{\mathrm{cr}}\left(\text { where } \mathrm{P}_{\mathrm{u}}>\mathrm{P}_{\mathrm{cr}}\right)
$$

where: $P_{\mathrm{cr}}$ - First Cracking Load

$\mathrm{P}_{\mathrm{u}}$ - Ultimate Load

$\delta_{\text {cr }}$ - First Cracking Deflection

$\delta_{u}$ - Ultimate Deflection

It is observed that when fibre volume is increased from 0 to $2.5 \%$ (with a $0.5 \%$ interval) in SMRCC slabs, there is a corresponding increase in the Deflection Ductility Index (DDI), from 1.34 to 8.42 when $\mathrm{MV}_{\mathrm{r}}=0.78 \%$, 2.17 to 9.57 when $\mathrm{MV}_{\mathrm{r}}=0.98 \%$, and 2.38 to 10.70 when $\mathrm{MV}_{\mathrm{r}}=1.23 \%$. The DDI of CS3, CS4, and CS5 are 1.34, 2.17, and 2.38, respectively. The results are similar to the experimental research work of Masood et al. (2003) [35], who used woven mesh and hexagonal steel wire mesh ( $0.40 \mathrm{~mm} \mathrm{dia})$, and a ratio of deflection at ultimate load to deflection at first crack (FC) load, which varied between 1.7 (lowest) and 2.51 (highest). Also, in the paper of Hossain and Awal (2010) [22] regarding ferrocement (reinforced with only mesh), the amount of ductility (deflection) at first crack varied based on the types of reinforcements used; the ductility at ultimate and failure loads was almost the same for all cases.

From Table 5 and Fig. 6, the DDI of SMRCC Type CS3 (with $\mathrm{MV}_{\mathrm{r}}=0.74 \%$ ) is 1.34, and for HMFRCBC Slab Types $3 \mathrm{~A}$ to $3 \mathrm{E}$ (with $\mathrm{MV}_{\mathrm{r}}=0.74 \%$ and $\mathrm{PO}-\mathrm{V}_{\mathrm{f}}=0.5-2.5 \%$ ) it ranges between 2.26 and 8.42, respectively. Similarly, for SMRCC Type CS4 (with $\mathrm{MV}_{\mathrm{r}}=0.98 \%$ ) the DDI is 2.17 , and for HMFRCBC Slab Types 4A to $4 \mathrm{E}$ (with $\mathrm{MV}_{\mathrm{r}}=0.98 \%$ and $\mathrm{PO}-\mathrm{V}_{\mathrm{f}}=0.5-2.5 \%$ ) the DDI varies from 3.81 to 9.57. For SMRCC Type CS5 (with $\mathrm{MV}_{\mathrm{r}}=1.23 \%$ ) the DDI is 2.38. For HMFRCBC Slab Types $5 \mathrm{~A}$ to $5 \mathrm{E}$ (with $\mathrm{MV}_{\mathrm{r}}=1.23 \%$ and $\mathrm{PO}-\mathrm{V}_{\mathrm{f}}=0.5-2.5 \%$ ) the DDI is between 4.77 and 10.70 . It is observed that the DDI of HMFRCBC is higher than that of SMRCC, which demonstrates better deflection ductility. Although when HMFRCBC demonstrates a higher level of flexural deflection ductility when compared to SMRCC (control specimens) as seen in Fig.6, the increase in the ductility index is attributable to the polyolefin fibres added along with the steel mesh in hybrid form.

On average, the DDI of HMFRCBC is 4 to 4.5 times that of SMRCC, demonstrating higher deflection ductility. From Fig.6, it is interesting to note that the Deflection Ductility Index increases with an increase in mesh and/ or fibre reinforcement [44]. 
Table 5. Flexural Load and Deflection Ductility of SMRCC and HMFRCBC (Slab Elements)

\begin{tabular}{|c|c|c|c|c|c|}
\hline Slab Reference & $\mathbf{P}_{\mathbf{c r}}{ }^{*}$ & $\mathbf{P}_{\mathbf{u}}{ }^{*}$ & $\boldsymbol{\delta}_{\mathbf{c r}}{ }^{* *}$ & $\boldsymbol{\delta}_{\mathbf{u}}{ }^{* *}$ & $\begin{array}{c}\mathbf{D D I}^{* *}= \\
\boldsymbol{\delta}_{\mathbf{u}} / \boldsymbol{\delta}_{\mathbf{c r}}\end{array}$ \\
\hline No. & $\mathbf{k N}$ & $\mathbf{k N}$ & $\mathbf{M m}$ & $\mathbf{M m}$ & $\mathbf{R a t i o}^{*}$ \\
\hline CS3 & 1.45 & 1.60 & 2.87 & 3.84 & 1.34 \\
\hline 3A & 1.50 & 1.85 & 2.15 & 4.85 & 2.26 \\
\hline 3B & 1.95 & 2.20 & 1.97 & 8.67 & 4.41 \\
\hline 3C & 1.60 & 2.60 & 1.87 & 10.78 & 5.76 \\
\hline 3D & 1.95 & 2.65 & 1.60 & 12.72 & 7.95 \\
\hline 3E & 2.05 & 2.70 & 1.54 & 12.96 & 8.42 \\
\hline CS4 & 1.65 & 2.05 & 2.65 & 5.74 & 2.17 \\
\hline 4A & 1.85 & 2.60 & 1.93 & 7.35 & 3.81 \\
\hline 4B & 2.25 & 2.80 & 2.00 & 11.44 & 5.72 \\
\hline 4C & 2.10 & 3.20 & 2.05 & 12.24 & 5.97 \\
\hline 4D & 2.10 & 3.25 & 1.64 & 13.74 & 8.38 \\
\hline 4E & 2.20 & 3.45 & 1.48 & 14.16 & 9.57 \\
\hline CS5 & 1.75 & 2.65 & 2.56 & 6.10 & 2.38 \\
\hline 5A & 2.20 & 2.80 & 1.62 & 7.73 & 4.77 \\
\hline 5B & 2.05 & 3.55 & 1.54 & 12.35 & 8.02 \\
\hline 5C & 2.10 & 3.60 & 1.42 & 12.63 & 8.89 \\
\hline 5D & 2.15 & 3.70 & 1.31 & 13.85 & 10.57 \\
\hline 5E & 2.30 & 3.30 & 1.19 & 12.74 & 10.70 \\
\hline
\end{tabular}

(Reference: *Sakthivel 2014 [10], 2015a [11-12]; **Sakthivel 2015, Ph.D. Thesis [45]; SMRCC-Steel Mesh-Reinforced Cementitious Composites; HMFRCBC-Hybrid Mesh-and-Fibre-Reinforced Cement Based Composite; ML-Mesh Layers; $\mathrm{MV}_{\mathrm{r}}=$ Mesh Volume of reinforcement; PO-Polyolefin Fibre; $\mathrm{FV}_{\mathrm{f}}=$ Fibre Volume Fraction (\%); $\mathrm{P}_{\mathrm{cr}}=$ First Cracking Flexural Load; $\mathrm{P}_{\mathrm{u}}=$ Ultimate Flexural Load; $\delta_{\mathrm{cr}}$-First Cracking Deflection; $\delta_{\mathrm{u}}=$ Ultimate Deflection; Deflection Ductility Index $(\mathrm{DDI})=\delta_{\mathrm{u}} / \delta_{\mathrm{cr}}$

\section{Deflection Ductility Index}

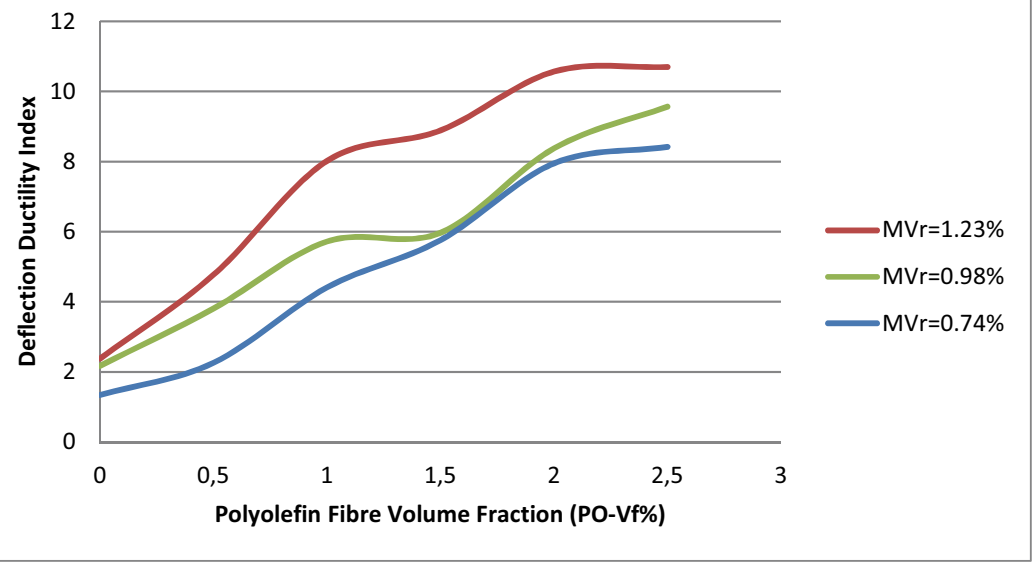

Fig. 6. Deflection Ductility Index of Slab Elements (under Flexural Loading) 


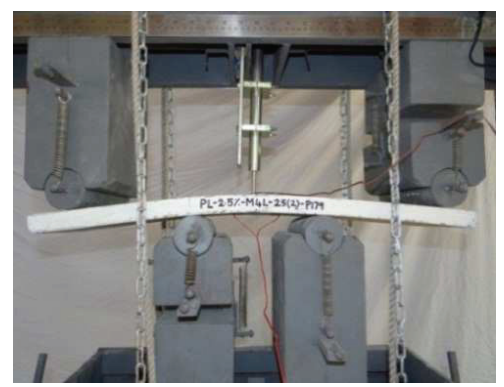

Fig. 7. Deflection Ductility of 4E

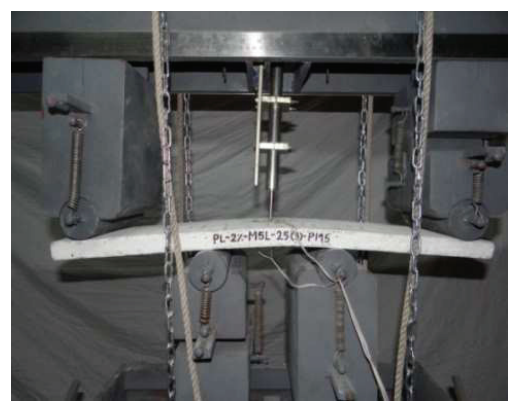

Fig. 9. Deflection Ductility of 5D

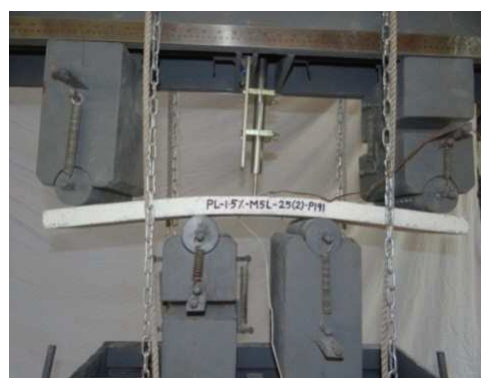

Fig. 8. Deflection Ductility of 5C

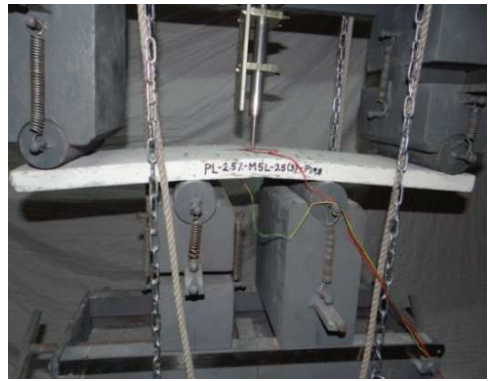

Fig. 10. Deflection Ductility of 5E

\section{Conclusions}

Steel Mesh-Reinforced Cementitious Composites (ferrocement) have some limitations in terms of element thickness and the number of reinforcing mesh layers and the resulting deflection ductility. In this study, polyolefin fibres are added to the sample to improve the material properties of ferrocement, especially its ductility. The author's concept of combining steel mesh and plastic (polyolefin) fibres as a new material combination meant to improve material properties of ferrocement, has shown that there is an improvement in flexural load and ductility performance of Hybrid Mesh-and-Fibre-Reinforced Cementitious Composites (HMFRCBC) in comparison with Steel Mesh-Reinforced Composites. Even though the first crack load and ultimate load values of SMRCC increase with increasing reinforcement volume fractions, the addition of fibres certainly has 
an effect on improving the deflection ductility of mesh-reinforced cementitious composites. The Deflection Ductility Index of HMFRCBC is higher than that of SMRCC. Also, when the PO fibre volume fraction is increased (from 0.5 to $2.5 \%$, with a $0.5 \%$ interval), the deflection ductility significantly improves.

Study results have shown that the maximum deflection ductility index (DDI) of slab elements of hybrid mesh (5 layers) and polyolefin fibre (of volume fraction $2.5 \%$ ) is 10.7 , which is almost 4.5 times as that of steel mesh-reinforced cementitious composites (control specimens). The hybrid meshand-fibre-reinforced cementitious composites, which can be cast as thin elements, show higher ductility than steel mesh-reinforced cementitious composites (ferrocement), and since this innovative construction material shows a failure pattern that is slow and steady and not sudden and catastrophic, it can be used in the construction industry 


\section{REFERENCES}

1. A.E. Naaman, Ferrocement and Laminated Cementitious Composites, Techno Press 3000, Ann Arbor, Michigan, USA, 2000.

2. ACI 549, State-of-the-Art Report on Ferrocement, ACI 549-R97 in Manual of Concrete Practice, American Concrete Institute, Farmington Hills, Michigan, 26 pages, 1997.

3. H.M. Ibrahim, "Experimental investigation of ultimate capacity of wire mesh-reinforced cementitious slabs." Construction and Building Materials, 25 (1): 251-259, 2011a, DOI: 10.1016/j.conbuildmat. 2010. 6. 032

4. H.M. Ibrahim, "Shear capacity of ferrocement plates in flexure, Engineering Structures, 33(5): 1680-1686, 2011b, DOI: 10.1016/j.engstruct.2011.02.004

5. M.J. Shannag and T.B. Ziyyad, "Flexural response of ferrocement with fibrous cementitious matrices." Construction and Building Materials, 21(6): 1198-1205, 2007, DOI: 10.1016/j.conbuildmat.2006.06.021.

6. S. Wang, A.E. Naaman and V.C. Li, "Bending response of hybrid ferrocement plates with meshes and fibres", Journal of Ferrocement, 34(1): 275-288, 2004, http://hdl.handle.net/2027.42/84723

7. V.W.J. Lin, S.T. Quek and M. Maalej, "Static and dynamic tensile behaviour of PE-fibrous ferrocement." Magazine of Concrete Research, 63(1): 61-73, 2011, DOI: 10.1680/macr.2011.63.1.61

8. L. Andal, M.S., Palanichamy, and M. Sekar (2008), "Strength and durability of polymer and flyash modified ferrocement roofing/ flooring elements", Proceedings of the $33^{\text {rd }}$ Conference on Our World in Concrete and Structures, Singapore, 25-27 August, 2007, http://cipremier.com/1000033009.

9. A.E. Naaman, "Evolution in ferrocement and thin-reinforced cementitious composites", Arabian Journal for Science and Engineering, 37(2): 421-441, 2012, DOI:10.1007/s13369-012-0187-4

10. P.B. Sakthivel, A. Ravichandran and N. Alagumurthi, "Flexural Strength and toughness of Polyolefin Fibre Reinforced Cementitious Composites embedded with Steel Mesh", Proceedings of the 3rd RILEM International Conference on Strain Hardening Cementitious Composites (SHCC3), Delft University of Technology, The Netherlands, 3-5th November, 441-448, 2014.

11. P.B. Sakthivel, A. Ravichandran and N. Alagumurthi, N., "Experimental Studies to determine the Flexural and Cracking Performance of Hybrid Steel Mesh and Polyolefin Fibre Reinforced Cementitious Composites", RILEM -7th International Workshop on High Performance Fibre Reinforced Cement Composites (HPFRCC-7) conducted by the University of Stuttgart, Germany, 01-03 June 1-3, 2015, pp.343-350, 2015a

12. P.B. Sakthivel, A. Ravichandran and N. Alagumurthi, "Flexural Behavior of Mesh-and-Fibre Reinforced Cementitious Composites", in Proceedings 11th International RILEM Symposium on Ferrocement and 3rd ICTRC International Conference on Textile Reinforced Concrete", (FERRO-11), held at RWTH Aachen University, Germany, June 07-10, pp.79-89, 2015b

13. H.D. Yun, I.S. Yang, S.W. Kim, E. Jeom, C.S. Choi, and H. Fukuyama, H., "Mechanical properties of HighPerformance Hybrid-Fibre Reinforced Cementitious Composites (HPHFRCCS)." Magazine of Concrete Research, 59(4): 257-271, 2007, DOI: 10.1680/macr.2007.59.4.257.

14. P. Zhang, C. Liu, Q. Li, and T. Zhang (2013), "Effect of polypropylene fibre on fracture properties of cement treated crushed rock", Composites: Part B, 55: 48-54, 2013, DOI:10.1016/j.compositesb.2013.06.005

15. T. Han, W. Lin, A. Cheng, R. Huang and C. Huang, "Influence of polyolefin fibres on the engineering properties of cementbased composites containing silica fume", Materials \& Design, 37: 569-576, 2012, DOI:10.1016/j.matdes.2011.10.038

16. S.F. Santos, G.H.D. Tonoli, J.E.B. Mejia, J. Fiorelli and H. Savastano Jr., "Non-conventional cement-based composites reinforced with vegetable fibres: A review of strategies to improve durability", Materiales De Construccion, 65(317): 1-20, 2015, DOI:10.3989/mc.2015.05514

17. A. Ghazy, M.T. Bassuoni, E. Maguire and M. O’Loan, "Properties of fibre-reinforced mortars incorporating nano-silica", Fibres, 4(1), 6: 1-16, 2016, DOI: 10.3390/fib-4010006.

18. M. Maalej and V.C. Li, "Flexural/tensile-strength ratio in Engineered Cementitious Composites", Journal of Materials in Civil Engineering, ASCE, 1994, 6(4): 513-528, 1994, DOI:10.1061/(ASCE)08991561(1994)6:4(513)

19. M.Z. Hossain and A.S.M.A. Awal, "Flexural response of hybrid carbon fibre thin cement composites", Construction and Building Materials, 25(2): 670-677, 2011a, DOI:10.1016/j.conbuildmat.2010.07022

20. M.Z. Hossain and A.S.M.A. Awal, "Experimental validation of a theoretical model for flexural modulus of elasticity of thin cement composite", Construction and Building Materials, 25(3): 1460-1465, 2011b, DOI:10.1016/j.conbuildmat.2010.09.018

21. T.M. Elrakib, Performance Evaluation of HSC beams with low flexural reinforcement", HBRC Journal, 9(1): 49-59, 2013, DOI:10.1016/j.hbrcj.2012.12.006

22. M.Z. Hossain and A.S.M.A. Awal, "A Study on flexural modulus and ductility of laminated cementitious composites", Malaysian Journal of Civil Engineering, 22(2):, 216-26, 2010. 
23. Z.S. Tabatabaei, J.S. Volz, D.I. Keener, and B.P. Gliha, "Comparative impact behavior of four long carbon fibre reinforced concretes.” Materials and Design, 55: 212-223, 2014, DOI:10.1016/ j.matdes.2013.09.048

24. K. Tosun-Felekoglu and B. Felekoglu, "Effects of fibre hybridization on multiple cracking potential of cement-based composites under flexural loading", Construction and Building Materials, 4: 15-20, 2013, DOI:10.1016/j.conbuildmat.2012.09.115

25. E. Ozbay, M. Sahmaran, H.E. Yucel, T.K. Erdem, M. Lachemi, and V.C. Li, "Effect of sustained flexural loading on self-healing of Engineered Cementitious Composites", Journal of Advanced Concrete Technology, 11(5): 167-179, 2013, DOI: 10.3151/jact.11.167

26. W.N. Al-Rifaie and M.M. Joma'ah (2010), "Structural Behaviour of Ferrocement System for Roofing", Diyala Journal of Engineering Sciences, First Engineering Scientific Conference, College of Engineering, University of Diyala, 22-23 December, pp.237-248.

27. IS 12269-1987 (Reaffirmed 2008), Specification for 53 Grade Ordinary Portland Cement, Bureau of Indian Standards, New Delhi, India

28. IS:383-1987, Specification for Coarse and Fine Aggregates from Natural Sources for Concrete (Second Revision), Ninth Reprint, September 1993, Bureau of Indian Standards, New Delhi, India.

29. P. Suthiwarapirak, T. Matsumoto and T. Kanda (2004), "Multiple cracking and fibre bridging characteristics of engineered cementitious composites under fatigue flexure", Journal of Materials in Civil Engineering, 16(5): 433-443, DOI:10.1061/(ASCE)0899-1561(2004)16:5(433)

30. M.A.A. Aldahdooh, N.M. Bunnori and M.A.M. Johari, "Influence of palm oil fuel ash on ultimate flexural and uniaxial tensile strength of green ultra-high performance fibre reinforced cementitious composites." Materials and Design, 54: 694 701, 2014, DOI:10.1016/j.matdes.2013.08.094

31. H.E. Yucel, H. Jashami and M. Sahmaran, "Thin ECC overlay systems for rehabilitation of rigid concrete pavements", Magazine of Concrete Research, 65(2), 108-20, 2013, DOI:10.1680/macr.12.00022

32. JCSE-SF4, Methods of tests for flexural strength and flexural toughness of steel fibre reinforced concrete, Concrete Library of JSCE, Japan Society of Civil Engineers, Tokyo, 1984, 3, 58-61.

33. ASTM C78/C78M-10, Standard Test Method for flexural strength of concrete (using simple beam with third point loading), ASTM International, 100 Bart Harbor Drive, PO Box C700, West Conshohocken, PA 19428-2959, USA, 2010.

34. M. Arif, P. Pankaj and S.K. Kaushik (1999), "Mechanical behavior of ferrocement composites: An Experimental Investigation", Cement and Concrete Composites, 21(4): 301-312, DOI:10.1016/S0958-9465(99)00011-6

35. A. Masood, M. Arif, S. Akhtar and M. Haquie (2003), "Performance of ferrocement panels in different environments", Cement and Concrete Research, 33(4): 555-562, DOI:10.1016/S0008-8846(02)01003-7

36. S.S. Gweli, P.J. Nedwell and C.G. Bailey, "The use of high performance non-metallic fibre in ferrocement", Proceedings of the third International Conference on Structural Engineering, , Mechanics and Computation, Cape Town, South Africa, Edited by A. Zingoni 10-12 September, 2007, Millpress, The Netherlands, pp.537538.

37. C.B. Cheah and M. Ramli, "Load capacity and crack development characteristics of HCWA-DSF high strength mortar ferrocement panels in flexure", Construction and Building Materials, 36: 348-357, 2012, DOI:101016/jconbuildmat.2012.05.034

38. M.Z. Hossain, M. Rokonuzzaman and S. Inoue, "Flexural behavior of cement composites panels reinforced with different types of meshes", Proceedings of the 30th Conference on Our World in Concrete \& Structures, 23-24 August, 2005, Singapore.

39. R.J. Phalke and D.G. Gaidhankar, "Flexural behaviour of ferrocement slab panels using welded square mesh by incorporating steel fibres", International Journal of Research in Engineering and Technology, 3(5): 756-763, 2014.

40. S.F.U. Ahmed and H. Mihashi (2011), "Strain Hardening Behavior of light weight hybrid polyinyl alcohol (PVA) fibre reinforced cement composites", Materials and Structures, 44: 1179-1191, DOI:10.1617/s11527-010-96918

41. P. Frantzis, "Effect of early-age temperature rise on the stability of rapid-hardening cement fibre composites", Journal of Materials in Civil Engineering, ASCE, Vol.18(4): 568-75, 2006, DOI:10.1061/(ASCE)08991561(2006)18:4(568)

42. N. Abushawashi and V. Vimonsatit, "Influence of mixture, wire mesh and thickness on the flexural performance of hybrid PVA fibre ferrocement panels", International Journal of Innovative Research in Science, Engineering and Technology, 3(9): 15805-15812, 2014, DOI:10.15680/IJIRSET.2014.0309002

43. F.U.A. Shaikh (2013), "Deflection hardening behaviour of short fibre reinforced fly ash based geopolymer composites." Materials and Design, 50: 674-682, 2013, DOI: 10.1016/j.matdes.2013.03.063

44. H.N. Atahan, B.Y. Pekmezci and E.Y. Tuncel (2013), "Behaviour of PVA Fibre-Reinforced Cementitious Composites under static and impact flexural effects", Journal of Materials in Civil Engineering, ASCE, 25(10): 1438-1445, DOI:10.1061/(ASCE)MT.1943-5533.0000691

45. P.B. Sakthivel, Flexural and Impact Performance of Hybrid mesh and fibre reinforced cement-based composites, Ph.D. Thesis, Pondicherry University, India, September 2015. 


\section{LIST OF FIGURES AND TABLES:}

Fig. 1. Plain/ Fibrous Cement Mortar over Steel Mesh

Rys. 1. Zwykłe / włókniste zaprawy cementowe nad siatką stalową

Fig. 2. Flexural Test Set-up (with test specimen)

Rys. 2. Przygotowanie do badania na zginanie (z próbkami do badań)

Fig. 3. Flexural Load-Deflection Curves (for Specimens CS3 \& 3A to 3E)

Rys. 3. Krzywe obciążenia zginającego w stosunku do odchylenia (dla próbek CS3 \& 3A do 3E)

Fig. 4. Flexural Load-Deflection Curves (for Specimens CS4 \& 4A to 4E)

Rys. 4. Krzywe obciążenia zginającego w stosunku do odchylenia (dla próbek CS4 \& 4A do 4E)

Fig. 5. Flexural Load-Deflection Curves (for Specimens CS5 \& 5A to 5E)

Rys. 5. Krzywe obciążenia zginającego w stosunku do odchylenia (dla próbek CS5 \& 5A do 5E)

Fig. 6. Deflection Ductility Index of HMFRCBC Slab Elements (under Flexural Loading)

Rys. 6. Wskaźnik Odchylenia Plastyczności elementów płyty cementowych materiałów kompozytowych zbrojonych siatką hybrydową oraz włóknami [HMFRCBC] (podczas obciążenia zginającego)

Fig. 7. Deflection Ductility of $4 \mathrm{E}$

Rys. 7. Odchylenie plastyczności 4E

Fig. 8. Deflection Ductility of 5C

Rys. 8. Odchylenie plastyczności 5C

Fig. 9. Deflection Ductility of 5D

Rys. 9. Odchylenie plastyczności 5D

Fig. 10. Deflection Ductility of 5E

Rys. 10. Odchylenie plastyczności 5E

Table 1. Specimen Identification and Reinforcement of SMRCC and HMFRCBC (Slabs)

Tabela 1. Identyfikacja i zbrojenie próbek cementowych materiałów kompozytowych zbrojonych siatką stalową

[SMRCC] oraz cementowych materiałów kompozytowych zbrojonych siatką hybrydową oraz włóknami [HMFRCBC] (Płyty)

Table 2. Properties of Steel Weld Mesh

Tabela 2. Właściwości siatki stalowej spawanej

Table 3. Properties of Polyolefin Fibres

Tabela 3. Właściwości włókien poliolefinowych

Table 4. Strength of Reference Control and Test Specimens

Tabela 4. Wytrzymałość referencyjnych próbek kontrolnych i do badań

Table 5. Flexural Load and Deflection Ductility of SMRCC and HMFRCBC (Slabs)

Tabela 5. Obciążenie zginające i odchylenie plastyczności cementowych materiałów kompozytowych zbrojonych siatką stalową [SMRCC] oraz cementowych materiałów kompozytowych zbrojonych siatką hybrydową oraz włóknami [HMFRCBC] (Płyty) 


\section{ODKSZTALCENIE PLASTYCZNOŚCI PLYT WYKONANYCH Z CEMENTOWEGO MATERIALU KOMPOZYTOWEGO WZMOCNIONEGO SIATKĄ HYBRYDOWĄ ORAZ WLÓKNAMI}

Słowa kluczowe: cementowe materiały kompozytowe, zginanie, odchylenie, plastyczność, siatkobeton, zbrojenie hybrydowe, siatka, włókna

\section{STRESZCZENIE:}

Cementowe materiały kompozytowe zbrojone siatką stalową (tradycyjnie znane jako siatkobeton) stanowią innowacyjny materiał składający się z hydraulicznej zaprawy cementowej oraz ciasno rozmieszczonych warstw ciągłej siatki stalowej o małej średnicy oczek do stworzenia sztywnej konstrukcji, a ze względu na swoją doskonałą wytrzymałość na zginanie są wykorzystywane jako prefabrykaty dachowe. Pomimo, że na przestrzeni ostatnich kilkudziesięciu lat na świecie wybudowano kilka konstrukcji siatkobetonowych (prefabrykowane i wylewane na miejscu pierwszorzędne oraz drugorzędne konstrukcje dachowe i elementy belkowe, panele ścienne, ściany zatrzymujące ziemię, prefabrykowane schody, ławki, sklepienia, kopuły, cienkie pergole oraz systemy ochrony przeciwsłonecznej, ściany graniczące z morzem, nadziemne zbiorniki wodne, podziemne zbiorniki ściekowe, baseny i łodzie - wymieniając jedynie kilka), istnieją pewne ograniczenia dotyczące grubości elementu, a także liczby warstw siatki zbrojeniowej oraz wynikowego odchylenia plastyczności. Plastyczność jest niezwykłym zjawiskiem umożliwiającym odkształcenie elementu przy lub w okolicach granicznego obciążenia niszczącego bez znacznej utraty jego wytrzymałości. O zachowaniu plastycznym świadczy jego zdolność do utrzymania wyższych poziomów obciążenia po pierwszym pękaniu na skutek dużych odkształceń. Poprzednie badania wskazują, że nieciągłe włókna mogą być dodane do matrycy cementowej cementowych materiałów kompozytowych zbrojonych siatką stalową w formie hybrydowej w celu poprawy jej wytrzymałości na zginanie oraz odchylenia plastyczności.

Głównym celem tego badania jest określenie odchylenia plastyczności na zginanie cementowych materiałów kompozytowych wzmocnionych siatką hybrydową oraz włóknami (elementy płyty o grubości $25 \mathrm{~mm}$ ) przy użyciu różnych kombinacji udziałów objętościowych siatki oraz włókna, a także określenie Wskaźnika Odchylenia Plastyczności takich materiałów kompozytowych. W celu przeprowadzenia badania na zginanie, odlane zostały próbki płyt cementowych materiałów kompozytowych wzmocnionych siatką hybrydową oraz włóknami w rozmiarze $700 \mathrm{~mm}$ $($ długość) $\times 200 \mathrm{~mm}$ (szerokość) $\times 25 \mathrm{~mm}$ (grubość) z kilkoma kombinacjami hybrydowej mieszanki zbrojeniowej ze Stalowej Siatki (3, 4, i 5 warstw o $\mathrm{MV}_{\mathrm{r}}=0,78,0,94$, oraz 1,23\%) oraz poliolefinowych (PO) (syntetyczne typu barchip) włókien $(0,5-2,5 \%$ wielkości próbek, z $0,5 \%$ przedziałem). Odlane zostały także elementy płyty z cementowych materiałów kompozytowych zbrojonych 3, 4 i 5-ma warstwami siatki stalowej. Ocynkowana siatka stalowa ma małą średnicę z oczkiem siatki wynoszącym $12,5 \mathrm{~mm}$, natomiast włókna poliolefinowe mają $54 \mathrm{~mm}$ długości (z współczynnikiem kształtu 101.8). Wykorzystano stosunek piasku i cementu wynoszący 2:1 oraz wody i cementu wynoszący 0.43. Zwyczajny Cement Portlandzki (Klasa OPC-53) wykorzystano do odlewania próbek, a naturalny piasek rzeczny przepływający przez sito $2,36 \mathrm{~mm}$ został użyty jako drobne kruszywo. Podczas gdy płyty z cementowych materiałów kompozytowych zbrojonych siatką stalową (próbki kontrolne) były odlewane ze zwykłej zaprawy cementowej, cementowe materiały kompozytowe zbrojone siatką hybrydową oraz włóknami zostały odlane z użyciem mokrej włóknistej zaprawy poliolefinowej z odpowiednim stosunkiem wody i cementu.

Stwierdzono, że wytrzymałość na ściskanie cylindrycznej kostki z utwardzonej poliolefinowej włóknistej zaprawy cementowej (Próbki Badań Referencyjnych [RTS] - RTS na 28 dni) zmienia się od 30,57 do 48,41 N/mm², podczas gdy 
włókna poliolefinowe o procentowym udziale objętościowym $\left(\mathrm{V}_{\mathrm{f}} \%\right)$ 0,5-2,5\%, zostały odpowiednio zastosowane w porównaniu z utwardzoną zwykłą zaprawą cementową (Referencyjne Próbki Kontrolne - RCS) o wartości 25,48 N/mm². Stwierdzono, że wytrzymałość na rozciąganie (próbka cylindryczna) utwardzonej poliolefinowej włóknistej zaprawy (na 28 dni) zmienia się od 4,78 do $7,43 \mathrm{~N} / \mathrm{mm}^{2}$, podczas gdy włókna poliolefinowe z $\left(\mathrm{V}_{\mathrm{f}} \%\right.$ ) 0,5-2,5\% zostały użyte w porównaniu z próbkami utwardzonej zwykłej zaprawy cementowej o wartości 4,56 N/mm². 28-dniowa wytrzymałość na zginanie belki pryzmatycznej z próbek poliolefinowej włóknistej zaprawy okazała się wynosić od 6,32 do 8,97 N/mm² wraz z użyciem włókien poliolefinowych o wartości odpowiednio $\mathrm{V}_{\mathrm{f}} \%=0,5-2,5 \%$, w porównaniu z próbkami zwykłej zaprawy cementowej wynoszącymi $5,36 \mathrm{~N} / \mathrm{mm}^{2}$.

W celu odlewania wyżej wspomnianej referencyjnej próbki kontrolnej oraz cementowych materiałów kompozytowych zbrojonych siatką stalową (elementy płyty do badań), przygotowano zwykłą zaprawę cementową w stanie suchym, zgodnie z wybranym stosunkiem piasku i cementu, a następnie (według stosunku wody i cementu) dodano wodę i dokładnie wymieszano. Do odlewania wyżej wspomnianej próbki badań referencyjnych oraz cementowych materiałów kompozytowych zbrojonych siatką hybrydową oraz włóknami, początkowo wymieszano suchą zaprawę cementową, a następnie równomiernie rozprowadzono w niej włókno poliolefinowe i wymieszano. Do zaprawy włóknistej stopniowo dodawano wodę, następnie dokładnie wymieszano produkty, a wówczas mokra zaprawa włóknista była gotowa do odlewania elementów cementowych materiałów kompozytowych zbrojonych siatką hybrydową oraz włóknami. W celu odlewania próbek płyt, najpierw wylana została $3 \mathrm{~mm}$ warstwa zaprawy stanowiącą podstawę (zaprawa oznacza zwykłą zaprawę cementową w przypadku cementowych materiałów kompozytowych zbrojonych siatką stalową, a zaprawa $\mathrm{z}$ włóknem poliolefinowym w przypadku cementowych materiałów kompozytowych zbrojonych siatką hybrydową oraz włóknami) na dnie formy, a następnie równomiernie, za pomocą kielni, rozprowadzono zaprawę właściwie wykańczając jej górną powierzchnię. Następnie na postawę kładziona jest pierwsza warstwa siatki stalowej. Na pierwszą warstwę siatki kładziona jest następnie kolejna warstwa zaprawy, a po jej równomiernym rozprowadzeniu i wykończeniu, na zaprawie umieszczana jest druga warstwa siatki. Proces ten powtarzany jest aż do uzyskania żądanej liczby warstw siatki $(3,4,5)$. Zarówno górne jak i dolne warstwy siatki utrzymywane przez $3 \mathrm{~mm}$ otulinę zbrojeniową za pomocą przekładek dystansowych. Na każdym etapie, zaprawa była (ręcznie) zagęszczana za pomocą ciśnienia odlewania ręcznego za pomocą kielni oraz poprawnie wykończona przed położeniem każdej warstwy siatki zbrojeniowej.

Po wymaganym okresie utwardzania próbek płyt cementowych materiałów kompozytowych zbrojonych siatką stalową oraz cementowych materiałów kompozytowych zbrojonych siatką hybrydową i włóknami (28 dni), w celu określenia odchylenia w przypadku sztywności na zginanie (w połowie rozpiętości elementu płyty), przeprowadzone zostały badania na zginanie. Próba obciążenia zginającego została przeprowadzona na próbkach płyt z wykorzystaniem podpory o rozpiętości $600 \mathrm{~mm}$ oraz wartości obciążenia wynoszącej jedną trzecią punktów (200 mm) belki rozporowej, zapewniając w ten sposób dokładne zgięcie w centralnym punkcie płyty. Obecne ustawienie obciążenia zostało odwrócone, aby lepiej zaobserwować widoczne pęknięcia po stronie naprężenia elementów płyty, natomiast podczas projektowania zostały uwzględnione także zewnętrzne deformacje związane z osadzaniem oraz skręcaniem. W celu zmierzenia odchylenia przy zginaniu próbki podczas załadunku, liniowy zmienny przetwornik różnicowy (LVDT - 100 $\mathrm{mm}$ ) został zamontowany na górnej części ramy w połowie rozpiętości (dotykając próbki płyty). Obciążenie zostało ręcznie przyłożone w kierunku pionowym, w małych krokach ku górze, za pomocą podnośnika hydraulicznego, a dla każdego przyrostu obciążenia (mierzonego przez ogniwo obciążnikowe) odpowiednie odchylenie zostało zarejestrowane z wykorzystaniem skomputeryzowanego systemu gromadzenia danych. Zauważono i poddano analizie równoczesne 
pomiary obciążenia, przy którym pojawia się pierwsza rysa pęknięcia oraz odchylenie środka rozpiętości, jak również graniczne obciążenie, przy którym pojawia się pęknięcie i odchylenie środka rozpiętości.

Zaobserwowano, że obciążenie, przy którym pojawia się pierwsza rysa pęknięcia oraz obciążenie graniczne zwiększają się wraz ze wzrostem udziału objętościowego zbrojenia, można również zauważyć, że udział objętościowy zbrojenia ma wyraźny wpływ na obciążenie graniczne; lub, innymi słowy, uważa się, że obciążenie zginające cementowych materiałów kompozytowych zbrojonych siatką stalową wzrosło wraz ze wzrostem liczby warstw siatki drucianej. Plastyczność zginania cementowych materiałów kompozytowych zbrojonych siatką hybrydową oraz włóknami porównano z tą odnoszącą się do kompozytów cementowych zbrojonych siatką stalową (próbki kontrolne, odlew z 3, 4 i 5-ma warstwami). Badanie wykazało, że nastąpiła poprawa obciążenia zginającego, przy którym pojawiła się pierwsza rysa pęknięcia $\left(\mathrm{P}_{\mathrm{cr}}\right)$, granicznego obciążenia zginającego $\left(\mathrm{P}_{\mathrm{u}}\right)$, a także Wskaźnika Odchylenia Plastyczności (DDI) cementowych materiałów kompozytowych zbrojonych siatką hybrydową oraz włóknami w porównaniu z kompozytami cementowymi zbrojonymi siatką stalową. Ponadto, w przypadku zwiększenia udziału objętościowego włókna poliolefinowego, znacznie poprawia się wartość Wskaźnika Odchylenia Plastyczności.

Wyniki cementowych materiałów kompozytowych zbrojonych siatką hybrydową oraz włóknami (HMFRCBC, elementy płyty) wykazały, że wytrzymałość na zginanie oraz plastyczność wzrasta wraz ze wzrostem objętości zbrojenia z włókien poliolefinowych. Wskaźnik Odchylenia Plastyczności Zginania (FDDI) elementów płyty z siatką hybrydową (5 warstw) z włóknem poliolefinowym (udział objętościowy 2,5\%) wynosi 10,7, czyli prawie 4,5 razy więcej niż w kompozytach cementowych zbrojonych siatką stalową (próbki kontrolne). W związku z tym, według niniejszego badania, w przypadku cienkich elementów płyt cementowych, zarówno siatki jak i włókien można używać w formie hybrydowej w celu poprawy ich plastyczności odchylenia. Cementowy materiał kompozytowy zbrojony siatką hybrydową oraz włóknami może stanowić innowacyjny materiał do praktycznych zastosowań w robotach budowlanych, ponieważ elementy mogą być odlewane w formie cienkiej warstwy. Ponadto, wspomniany materiał wykazuje lepszą wytrzymałość na zginanie oraz większą plastyczność niż kompozyty cementowe zbrojone siatką stalową, a ewentualne uszkodzenia jego elementów są procesem powolnym i stałym, a nie nagłym i katastrofalnym. 